\title{
Asuransi Tanggung Jawab Produk dan Perlindungan Terhadap Konsumen
}

\author{
Ahmad Sudiro \\ Dosen Tetap Fakultas Hukum Universitas Tarumanagara \\ Jl. Letjend. S. Parman No. 1 Grogol - Jakarta Barat 11440 \\ ahmads@fh.untar.ac.id.
}

\begin{abstract}
Product liability insurance is an important issue if it is associated with the protection of consumers. This is a form of producer's responsibility in providing their protection to consumers who suffered losses as a result of using defective products. In this study, the problem is how the product liability insurance takes an important role in protecting the interests of consumers who suffered losses as a result of using a defective product, relating to the protection of consumers as the users of the product. This is a normative study employing the approach of legislation and conceptual. The results showed that the role of the insurance company as an insurer is taking over the responsibility of the manufacturer to the risk of losses due to product defects in the claims done by the consumers who suffered losses due to the defective product. Thus, the coverage of the product liability insurance is basically to protect and guarantee the right of consumers to the demands of compensation to producers.
\end{abstract}

Keywords: Insurance product liability, consumer protection.

\begin{abstract}
Abstrak
Asuransi tanggung jawab produk merupakan isu penting jika dikaitkan dengan perlindungan terhadap konsumen. Hal ini sebagai bentuk tanggung jawab produsen dalam memberikan perlindungan kepada konsumen yang menderita kerugian akibat menggunakan produk yang cacat. Dalam penelitian ini yang menjadi permasalahan adalah bagaimana peran asuransi tanggung jawab produk dalam memproteksi kepentingan konsumen yang menderita kerugian akibat menggunakan suatu produk yang cacat, berkaitan dengan perlindungan terhadap konsumen sebagai pengguna produk. Penelitian ini merupakan penelitian normatif, dengan pendekatan perundang-undangan dan konseptual. Hasil penelitian menunjukan bahwa peran perusahaan asuransi sebagai penanggung adalah mengambil alih tanggung jawab produsen terhadap risiko terjadinya kerugian akibat cacat produk yang di klaim oleh konsumen yang mengalami kerugian akibat adanya produk cacat tersebut. Dengan demikian pertanggungan asuransi tanggung jawab produk, pada dasarnya untuk melindungi dan menjamin hak konsumen atas tuntutan ganti kerugian kepada produsen.
\end{abstract}

Kata kunci: Asuransi tanggung jawab produk, perlindungan konsumen 


\section{Pendahuluan}

Perlindungan konsumen menjadi isu yang sangat penting terkait dengan pasar bebas, dimana arus keluar masuk barang tidak boleh dihambat. Konsekuensi dari perdagangan bebas ini adalah adanya kompetisi yang fair di antara produsen dan keseimbangan antara kepentingan produsen dengan konsumen. Kualitas produk menjadi indikator utama bagi konsumen, sedangkan biaya produksi yang rendah menjadi kepentingan utama produsen. Namun keseimbangan demikian sangat rentan.

Selain itu asuransi tanggung jawab produk merupakan isu penting yang perlu untuk dikaji dan dibahas secara mendalam untuk mendapatkan suatu solusi terhadap penggantian kerugian yang dialami konsumen akibat penggunaan suatu produk yang cacat. Oleh karena itu kehadiran asuransi tanggung jawab produk, di satu sisi dapat memberikan jaminan kepada konsumen untuk penggantian kerugian yang dialaminya. Di sisi yang lain, adanya asuransi tanggung jawab produk akan dapat membantu produsen atas penggantian kerugian konsumen, khususnya kerugian dalam jumlah besar. Dengan demikian, asuransi tanggung jawab produk dapat memberikan keuntungan, baik kepada produsen maupun konsumen. ${ }^{1}$

Keuntungan bagi produsen yang mengasuransikan tanggung jawab produknya, adalah dapat meringankan tanggung jawab atas tuntutan ganti kerugian konsumen khususnya dalam skala besar, karena telah digantikan oleh perusahaan asuransi untuk membayar kerugian tersebut. Sementara keuntungan bagi konsumen, yaitu adanya jaminan dan kejelasan pihak yang bertanggung jawab dalam penggantian kerugian yang dialami. Perusahaan asuransi sebagai penanggung mengambil alih posisi produsen dalam proses penyelesaian ganti kerugian terhadap konsumen, baik di luar maupun di dalam pengadilan. Dalam konsep asuransi tanggung jawab produk, maka produsen diwajibkan membayar premi atas produk yang diasuransikannya. Premi yang dibayar oleh produsen ini, sebagai dana untuk penggantian kerugian yang dialami konsumen. ${ }^{2}$

1 Luke M. Froeb and Paul A. Pautler, "Consumer Protection", Law and Economics Working Vanderbilt University Law School, 2007, hlm. 11,http:/ / ssrn.com/abstractjd=980781.

2 Craig F. Stanovich, "Duty to Defend in the CGL Policy", 2002, hlm. 4, IRMI Online. 
Dalam tatanan perdagangan bebas, konsumen memiliki posisi yang penting dan utama. Fenomena ini tergambar dalam pemberlakuan hukum perlindungan konsumen di hampir setiap negara, termasuk negara-negara berkembang di kawasan Asia Tenggara. ${ }^{3}$ Perlindungan konsumen sangat penting, karena dalam pelaksanaannya membutuhkan kerja sama dan koordinasi antara lembaga-lembaga terkait dengan pengawas perlindungan konsumen. Di Amerika Serikat, kewenangan melaksanakan perlindungan konsumen berada pada Federal Trade Commission (FTC). FTC bekerja sendiri atau pun bersama bergantung pada kebutuhan dan relevansi dengan kasus yang dihadapi. Perhatian utama FTC dalam melaksanakan perlindungan konsumen terkait dengan a deception free market place and provide the highest quality products at competitive prices. ${ }^{4}$

\section{Rumusan Masalah}

Berdasarkan uraian pendahuluan di atas, maka permasalahan yang muncul adalah bagaimana peran asuransi tanggung jawab produk dalam memproteksi kepentingan konsumen yang menderita kerugian akibat menggunakan suatu produk yang cacat, berkaitan dengan perlindungan terhadap konsumen sebagai pengguna produk?

\section{Tujuan Penelitian}

Penelitian ini ditujukan untuk mengetahui dan mengkaji peran asuransi tanggung jawab produk dalam rangka memproteksi kepentingan konsumen yang menderita kerugian karena menggunakan produk cacat, dan dikaitkan dengan sistem perlindungan terhadap konsumen sebagi pengguna produk tersebut.

\footnotetext{
Sheeta Sahoo and Aman Chatterjee, "Consumer Protection", 2009, hlm. 2, http:/ / ssrn.com/abstract=1452526.

4 Jillian G. Brady, "Consumer Protection in the United States: An Overview", Working Paper Loyola University Chicago School of Law, 2008, hlm. 3, http://ssrn.com/abstract=1000226.
} 


\section{Metode Penelitian}

Hadirnya sebuah metode penelitian dalam suatu pencarian kebenaran ilmiah merupakan suatu hal yang niscaya. Hal ini sebagaimana diungkapkan oleh Robert Bogdan dan Steven J Taylor seperti dikutip dalam Soerjono Soekanto, bahwa yang dimaksud dengan penelitian ilmiah adalah the process, principles and procedures by which approach problems and seek answer. In the social science, the terms to how to conduct research. 5 Penelitian ini merupakan penelitian normatif dengan pendekatan kualitatif. Objek yang dikaji dan dianalisis dalam penelitian ini adalah norma hukum yang terdapat pada peraturan perundang-undangan yang mengatur masalah asuransi tanggung jawab produk berkaitan dengan perlindungan terhadap konsumen dalam penyelenggaraan transportasi udara di Indonesia.

Hal ini diharapkan dapat memberikan gambaran secara jelas mengenai masalah asuransi tanggung jawab produk dan perlindungan terhadap konsumen, yang sangat berkaitan dengan tanggung jawab produsen sebagai salah satu bagian penting dalam proses kegiatan penyelenggaraan transportasi udara secara keseluruhan. Penelitian ini menggunakan data sekunder yang diperoleh melalui studi kepustakaan, dengan mengumpulkan bahan hukum primer, bahan hukum sekunder, dan bahan hukum tersier. ${ }^{6}$ Selain mendasari pada data sekunder di atas, dalam rangka melengkapi data yang ada juga dilakukan studi komparatif dengan perbandingan kepada negara lain terkait isu yang sama.

\section{Hasil Penelitian dan Pembahasan}

Produsen dalam konstelasi hukum perlindungan konsumen, dapat diartikan sebagai: A manufacturer is defined to mean a person who is a designer, formulator, constructor, rebuilder, fabricator, producer, compounder, processor, or assembler of any product or any component part thereof and who places the product or any component part thereof in the stream of commerce. Under the definition of manufacturer,

${ }^{5}$ Soerjono Soekanto, Pengantar Penelitian Hukum, Universitas Indonesia Press, Jakarta, 1996, hlm. 8.

${ }^{6}$ Soerjono Soekanto \& Sri Mamudji, Penelitian Hukum Normatif: Suatu Tinjauan Singkat, Raja Grafindo Persada, Jakarta, 2005, hlm. 17. 
almost any entity involved in the design, fabrication or assembly of the product will be included within the statute of repose. ${ }^{7}$

Dengan demikian produsen berarti pihak yang membuat suatu produk menjadi ada. Produk yang dibuat itu membutuhkan pasar, dimana produsen dan konsumen yang saling membutuhkan dapat mengadakan transaksi, dan sifat hubungannya tidak terputus. Dalam konstruksi hubungan tersebut, kedudukan antara produsen dengan konsumen seringkali dalam posisi yang tidak seimbang.

Oleh karena kedudukan konsumen yang lemah, maka hukum harus melindunginya. Apalagi salah satu sifat dan tujuan hukum untuk memberikan perlindungan atau pengayoman kepada masyarakat. Salah satu perlindungan konsumen ini misalnya dengan kuantitas dan kualitas informasi yang disampaikan produsen berkaitan dengan produk yang dipasarkan. ${ }^{8}$ Apabila penyampaian informasi dilakukan secara lengkap, maka produsen dapat beranggapan bahwa masyarakat telah mengetahui produk yang dibelinya. ${ }^{9}$ Oleh karena itu berlaku doktrin caveat emptor atau let the buyer beware, sehingga produsen berkewajiban untuk menyediakan informasi produk selengkap dan sebenar-benarnya. ${ }^{10}$

Di Indonesia, cacat produk didefinisikan sebagai produk yang tidak dapat memenuhi tujuan pembuatannya baik karena kesengajaan atau kealpaan dalam proses maupun disebabkan hal-hal lain yang terjadi dalam peredarannya, atau tidak menyediakan syarat-syarat keamanan bagi manusia atau harta benda mereka dalam penggunaannya, sebagaimana diharapkan konsumen. ${ }^{11}$ Ada beberapa kategori, jika suatu produk dapat disebut cacat atau tidak dapat memenuhi tujuan pembuatannya. Pertama, cacat pembuatan atau manufaktur, yaitu keadaan produk yang umumnya berada di bawah tingkat harapan konsumen. Produk cacat itu dapat membahayakan harta benda, kesehatan tubuh

\footnotetext{
${ }^{7}$ R. Brent Cooper and Diana L. Faust, "Products Liability", House Bill 4 Symposium Issue, South Texas Law Review Inc., 2005, hlm. 159.

8 Marianus Gaharpung, “Upaya Perlindungan Hukum Bagi Konsumen”, Jakarta, 14 Januari 2009, hlm. 21, http://Marianusgaharpung.wordpress.comlmakalah-hukum/ hukum-perlindungan-konsumen/.

9 Heidi Mandanis Schooner, "Consuming Debt: Structuring the Federal Response to Abuses in Consumer Credit”, Loyola Consumer Law Review, Vol. 18, No.36, Loyola University of Chicago School of Law, 2005, hlm. 50.

${ }^{10}$ Jillian G. Brady, Lo. Cit., hlm. 4.

11 A.Z. Nasution, Hukum Perlindungan Konsumen, Diadit Media, Jogjakarta, 2001, hlm. 148.
} 
atau jiwa konsumen. Kedua, cacat desain, sebab jika desain produk telah dipenuhi sebagaimana mestinya, maka peristiwa yang merugikan konsumen dapat dihindari. Ketiga, cacat peringatan atau instruksi, yaitu cacat produk karena tidak dilengkapi dengan peringatan-peringatan tertentu atau instruksi penggunaan tertentu yang tidak memadai. ${ }^{12}$

Di Amerika Serikat, terdapat tiga perspektif pendekatan penerapan perlindungan konsumen berkaitan dengan tanggung jawab produsen, yaitu: (1) Perspektif pelanggar melalui penegakan langsung hukum perlindungan konsumen dan hukum anti penipuan serta perlawanan terhadap skema/ rencana tertentu; (2) Perspektif konsumen individu melalui pengadaan alat/ fasilitas untuk perlindungan diri sendiri dan pendidikan konsumen; serta (3) Perspektif dari suatu grup konsumen tertentu. ${ }^{13}$ Dari ketiga perspektif pendekatan penerapan perlindungan terhadap konsumen tersebut, maka dapat dijelaskan sebagai berikut: Pendekatan pertama, berkenaan dengan pemberian ganti kerugian sampai kepada tindakan-tindakan produsen yang dikategorikan sebagai tindak pidana. Pendekatan kedua, menggambarkan kemandirian dan kematangan konsumen dalam melindungi kepentingan berkaitan dengan produk yang dipergunakannya melalui jalur hukum dan pendidikan. Pendekatan demikian sangat strategis dalam hukum perlindungan konsumen. Oleh karena konsumen diberdayakan melalui sosialisasi produk dan penggunaan jalur hukum untuk menegakkan hukum perlindungan konsumen dalam kaitannya dengan produk berbahaya dan penipuan yang dilakukan produsen. Pendekatan ketiga, mengandung kelemahan, karena tidak mudah untuk menentukan konsumen yang dimaksud. Dengan demikian, diperlukan kehati-hatian untuk menentukan konsumen tersebut melalui sejumlah variabel, seperti usia, tingkat pendapatan, etnisitas, gender, profesi, dan lain-lainnya. ${ }^{14}$

Kecenderungan produsen berusaha memperoleh keuntungan salah satunya dengan adanya keanekaragaman jenis produk. Namun disisi lain dapat menimbulkan berbagai risiko atas keselamatan konsumen. Hal ini akan

12 Ibid., hlm. 149.

13 David Adam Friedman, "Reinventing Consumer Protection", De Paul Law Review, Vol. 57, No. 114, Willamette University, 2007, hlm. 32, http://ssm.comlabstract=984082.

${ }^{14}$ Ibid., hlm. 34. 
menimbulkan konsekuensi yang kompleks berkaitan hubungan antara produsen dengan konsumen, dan menunjukan adanya keanekaan yang terorganisir dan saling terkait satu sama lain. Terdapat dua tingkatan kompleksitas dalam konteks ini. Pertama, mengenai jenis produk itu sendiri, apakah merupakan produk akhir, produk bahan baku, atau produk dari komponen suatu barang. Kedua, kompleksitas dari jenis produk tersebut misalnya automobile, pesawat udara, atau produk-produk komponen penunjangnya. Demikian juga kompleksitas hubungan produsen dengan konsumen bahwa tidak semata-mata produsen bertanggungjawab terhadap produk yang disediakannya dan konsumen memiliki hak untuk meminta pertanggungjawaban tersebut. ${ }^{15}$

Perusahaan-perusahaan baik yang berada di Amerika Serikat maupun perusahaan yang memasok produk dari negara lain, dapat mengurangi kemungkinan risiko klaim tanggung jawab produk melalui program manajemen risiko. Oleh karena tidak ada bisnis yang dapat secara menyeluruh menghilangkan risiko klaim tanggung jawab produk. Untuk itu dibutuhkan asuransi, sebagai salah satu mekanisme yang digunakan untuk meminimalkan risiko yang berakibat adanya kerugian pada perusahaan. ${ }^{16}$ Terdapat dua pertimbangan utama produsen berkaitan dengan asuransi tanggung jawab produk, yaitu penutupan polis dan biaya premi. Dalam hal ini, produsen harus menjamin bahwa polis tanggung jawab produk itu menyediakan pertanggungan yang memadai dan berisi ketentuan-ketentuan yang bermanfaat bagi produsen tersebut. Oleh karena itu asuransi tanggung jawab produk sangat penting dalam memperkuat produsen sebagai pihak yang benar-benar harus bertanggung jawab atas kesalahannya. ${ }^{17}$

Asuransi merupakan suatu persetujuan dimana pihak yang menjamin berjanji kepada pihak yang dijamin untuk menerima sejumlah uang premi sebagai pengganti kerugian yang mungkin akan diderita oleh yang dijamin

${ }^{15}$ Mark Mildred, Product Liability Law and Insurance, Maxwell Publishing, London, 2000, hlm. 61.

${ }^{16}$ John F. Zulack \& Jennifer K. King, "Products Liability Prevention: What Every International Business Should Know About Selling Products in the United States", International Law Practicum Spring, New York State Bar Association, 2003, hlm. 43.

${ }^{17}$ Kenneth S. Abraham, "Liability Insurance and Accident Prevention: The Evolution of an Idea", Maryland Law Review, Vol. 64, No. 128, 2005, hlm. 573. 
karena akibat dari suatu peristiwa yang belum jelas. ${ }^{18}$ Pasal 1 Butir 1 Undangundang No. 2 Tahun 1992 tentang Usaha Perasuransian, menyatakan bahwa asuransi atau pertanggungan adalah perjanjian antara dua pihak atau lebih, dengan mana pihak penanggung mengikatkan diri kepada tertanggung, dengan menerima premi asuransi, untuk memberikan penggantian kepada tertanggung karena kerugian, kerusakan, atau kehilangan keuntungan yang diharapkan, atau tanggung jawab hukum kepada pihak ketiga, yang mungkin akan diderita tertanggung, yang timbul dari suatu peristiwa yang tidak pasti, atau untuk memberikan suatu pembayaran yang didasarkan atas meninggal atau hidupnya seseorang yang dipertanggungkan. Sedangkan sebelum Undang-undang tersebut berlaku, pemahaman asuransi dapat ditemukan dalam Pasal 246 Kitab UndangUndang Hukum Dagang (KUHD) yang menyatakan bahwa asuransi/ pertanggungan adalah perjanjian dimana penanggung mengikatkan diri kepada tertanggung dengan menerima premi, untuk memberikan penggantian kepadanya karena suatu kerugian, kerusakan, atau kehilangan keuntungan yang diharapkan, yang mungkin akan dideritanya akibat dari suatu peristiwa tidak pasti.

Dalam liberalisasi perdagangan antar negara sebagaimana telah diatur Organisasi Perdagangan Dunia/World Trade Organization (WTO) yang menghendaki penghapusan kendala perdagangan/trade barriers. Sebagai konsekuensi dari sistem itu, maka produk berbagai negara akan masuk ke dalam pasar domestik, yang selanjutnya dapat menimbulkan persoalan berkaitan dengan keanekaragaman produk sekaligus persoalan hukum yang berkaitan dengan perlindungan konsumen.

Oleh karena itu doktrin caveat emptor dalam hukum perlindungan konsumen dianggap tidak lagi sesuai dalam era globalisasi saat ini. ${ }^{19}$ Beberapa faktor yang menyebabkan hal itu antara lain pemasaran produk yang tidak berguna dan berbahaya, pengepakan yang tidak higienis untuk produk makanan, dan lain-lainnya. Informasi produk-produk demikian boleh jadi tidak terbuka,

18 Wirjono Prodjodikoro, Hukum Asuransi di Indonesia, Intermasa, Jakarta, 1987, hlm. 2.

19 Donna S. Harkness, "Packaged and Sold: Subjecting Elder Law Practice to Consumer Protection Laws", Journal of Law and Policy, Vol. 80, No. 160, 2003, hlm. 253, http:/ /www.westlaw.com. 
dan menyesatkan bahkan mengandung unsur penipuan, sehingga doktrin caveat emptor tidak akan mampu untuk melindungi konsumen.

Dengan demikian perlindungan konsumen menjadi isu hukum yang sangat penting dalam konstelasi rejim perdagangan bebas. Walaupun Pemerintah Indonesia proaktif untuk menarik investor asing, tetapi disisi lain belum disertai dengan sistem kebijakan, perundang-undangan, birokrasi, dan jaminan rasa aman yang memadai bagi konsumen. ${ }^{20}$ Salah satu cara untuk melindungi konsumen yaitu dengan menerapkan sertifikasi atas semua produk yang masuk ke suatu negara, atau produk yang diproduksi oleh perusahaan negara yang bersangkutan. Sertifikasi ini mengimplikasikan adanya standarisasi tertentu yang diberlakukan terhadap produk, sehingga pemerintah wajib proaktif dalam memberikan perlindungan kepada konsumen. ${ }^{21}$

Banyaknya kasus gugatan tanggung jawab produsen yang didaftarkan setiap tahun di pengadilan negara bagian dan federal Amerika Serikat, menunjukkan kepedulian konsumen atas kepentingan hak-haknya. Sedangkan dasar hukum untuk gugatan tanggung jawab produk sangat luas, terdiri dari tanggung jawab untuk cacat produksi, cacat desain, dan kegagalan/ kesalahan dalam memberi peringatan. Kasus-kasus tanggung jawab produk tersebut mendapat perhatian signifikan dari media, khususnya ketika kasus itu terkait dengan produk-produk yang dijual secara luas di pasar yang merugikan banyak konsumen. Tanggung jawab produk semakin dianggap penting di luar Amerika Serikat, khususnya di Uni Eropa dan Asia. Apabila tanggung jawab produk ini diabaikan, maka dapat mengancam kesehatan keuangan perusahaan sehingga perusahaan mencari jalan untuk mengelola risiko-risiko tanggung jawab produk bagi organisasinya melalui asuransi. ${ }^{22}$

Dari pandangan produsen, asuransi bagaikan pedang bermata dua. Di satu sisi asuransi dimaksudkan untuk mengantisipasi tuntutan/ gugatan ganti

\footnotetext{
${ }^{20}$ J. Satrio, "Mencemaskan Masuknya Investasi Asing”, Kompas, 4 Peb 2006, hlm. 2.

21 Peter H. Shuck, "Tort Liability to Those Injured by Negligence Accreditation Decisions, Law and Contemporary Problems Autumn", Private Accreditation in the Regulatory States, Vol.57, No.114, 1994, hlm. 193.

${ }^{22}$ Kevin M. Quinley, "Product Liability Cushions the Blow of Risk Management, How to Bulletproof Your Company from the Minefield in Today's Litigious Society", USA: Pergamon Press, 2006, hlm. 2 http://www.mpomag.comlartic1es/2006/05/product-liability-cushions-the-blow-of-risk-manage.
} 
kerugian yang muncul karena penggunaan produk yang dihasilkan atau dijual. ${ }^{23}$ Namun pada sisi lain, asuransi juga merupakan biaya yang berkaitan dengan tanggung jawab produk yang ditanggung oleh perusahaan dalam aktifitas usahanya. Sedangkan dua biaya lainnya adalah yang berkaitan dengan usaha preventif untuk menghindari terjadinya kecelakaan (technical cost) dan biayabiaya untuk proses perkara di pengadilan. ${ }^{24}$

Dari segi kebutuhan pengalihan risiko, perusahaan asuransi berperan sebagai penanggung atas tuntutan/gugatan yang diajukan oleh konsumen. Selain itu lembaga asuransi dimaksudkan untuk memenuhi permintaan atau tuntutan masyarakat dalam menciptakan keseimbangan kepentingan konsumen dan produsen, dengan memberikan ruang lingkup jaminan atas risiko tanggung jawab akibat kecelakaan atau kerusakan yang diderita oleh konsumen. ${ }^{25}$

Asuransi tanggung jawab produk merupakan suatu perkembangan atau proses yang diharapkan dapat mengatasi atau memenuhi kebutuhan perlindungan terhadap tanggung jawab produk. Black's Law Dictionary merumuskan asuransi tanggung jawab produk sebagai berikut: "An agreement to indemnify a manufacturer, supplier or retailer for a loss arising from the insured's liability to user who is harmed by any product manufactured or sold by the insured". ${ }^{26}$

Kebutuhan produsen atas jasa asuransi tanggung jawab produk merupakan dampak lanjutan dari perkembangan pada bidang hukum tanggung jawab produk yang berkembang begitu cepat dan semakin kompleks. Hal ini tergambar dari tanggapan Asosiasi Dewan Asuransi Internasional (International Association of Insurance Councel), yang menyatakan sebagai berikut:

"There is a growing tendency among the courts and writers to seek to make the manufacturer liable in these case regardless of the arguments concerning privity of contract ... This change in the concept of the law can be traced directly to our changing political philosophy and theory of protecting the general public through social security and other legislative measures. Thus, it is that we can see the courts leaning toward the imposition of liability upon the source (that is, the manufacturer) regardless of the

${ }^{23}$ Rowland H. Long, The Law of Liability Insurance, New York: Matthew Bender \& Company Incorporated, 1999, hlm. 112.

24 Inosentius Samsul, Perlindungan Konsumen, Kemungkinan Penerapan Tanggung Jawab Mutlak, Fakultas Hukum Universitas Indonesia, Jakarta, 2004, hlm. 238.

${ }^{25}$ Marc S. Mayerson, "Perfecting and Pursuing Liability Insurance Coverage a Primer for Policyholders on Complying with Notice Obligations”, Torts \& Insurance Law Journal, Vol.12, No.24, Summer, 1997, hlm. 107. hlm. 125.

${ }_{26}$ Bryan A. Garner, Black's Law Dictionary, 7th Edition, St. Paul Minnesota, West Publishing Co., 1999, 
number of intermediary chanes through which the product has traveled to reach the injured customer or user". 27

Dewan tersebut menyatakan bahwa jumlah kasus/sengketa gugatan tanggung jawab produk mengalami peningkatan dibandingkan dengan sebelumnya. Sedangkan biaya untuk advokat yang menangani kasus atau sengketa konsumen juga mengalami peningkatan jika dibandingkan dengan kasus atau sengketa lainnya. Selain itu data yang dikeluarkan oleh Lembaga Penelitian Putusan Pengadilan di Cleveland Ohio - Amerika Serikat, melaporkan bahwa jumlah tuntutan ganti kerugian yang dikabulkan dalam putusan kasus/sengketa gugatan tanggung jawab produk senilai dua kali lipat jika dibandingkan dengan nilai gugatan yang dikabulkan dalam kasus lainnya. ${ }^{28}$

Peningkatan risiko produsen di Indonesia setelah berlakunya UndangUndang No. 8 Tahun 1999 tentang Perlindungan Konsumen, dapat dilihat dari aspek hukum materiil yang menerapkan beban pembuktian terbalik, dan aspek formil yang membentuk lembaga penyelesaian sengketa serta cara mengajukan gugatan melalui class action dan legal standing. Undang-Undang No. 8 Tahun 1999 mengkategorikan produk dalam bentuk barang dan jasa, sehingga undangundang perlindungan konsumen mengakui dua bentuk tanggung jawab, yaitu product liability yang berkaitan dengan barang, dan professional liability yang berkaitan dengan jasa. Pasal 1 Butir 4 Undang-Undang No. 8 Tahun 1999 menyatakan bahwa "Barang adalah setiap benda baik berwujud maupun tidak berwujud, baik bergerak maupun tidak bergerak, dapat dihabiskan maupun tidak dapat dihabiskan, yang dapat untuk diperdagangkan, dipakai, dipergunakan, atau dimanfaatkan oleh konsumen". Sedangkan Pasal 1 Butir 5 undang-undang Perlindungan Konsumen, menyatakan bahwa "Jasa adalah setiap layanan yang berbentuk pekerjaan atau prestasi yang disediakan bagi masyarakat untuk dimanfaatkan oleh konsumen".

Namun di Indonesia sampai saat ini belum mampu secara optimal dalam menjamin tanggung jawab hukum para produsen serta penjual untuk membayar ganti kerugian kepada para pengguna, pembeli dan bahkan pengecer karena

27 Ray H. Andersen, "Current Problem in Product Liability Law and Product Liability Insurance", Insurance Counsel Journal, Vol. 31, No. 62, July 1964, hlm. 435.

${ }^{28}$ Ibid., hlm. 436. 
kerugian atau kerusakan yang diderita akibat cacat produk, khususnya produk yang berasal dari negara lain. Sebagai perbandingan, produsen di Amerika Serikat diwajibkan menutup asuransi atas produk-produknya yang di ekspor ke negara lain. ${ }^{29}$ Apalagi adanya perbedaan penggunaan sistem hukum suatu negara menjadi kompleksitas dalam pemberian perlindungan atas produk dalam negeri terhadap produk yang datang dari luar negara. Oleh karena hukum perlindungan konsumen dirancang untuk menyeimbangkan insentif produsen, dengan tujuan melindungi konsumen dengan mencegah perilaku tertentu yang merugikan konsumen. ${ }^{30}$

Selain itu penerapan hukum perlindungan konsumen ternyata tidak terlepas dari berbagai hambatan. Dalam hal ini ada 3 (tiga) penghambat potensial, yaitu state constitutional separation of powers, statutory construction, and policy considerations relating to the professional stature of attorneys. ${ }^{31}$ Pemisahan kekuasaan menghasilkan kepentingan politik yang dapat berbeda antara eksekutif dengan legislatif. Kekuasaan legislatif dapat menentukan substansi hukum perlindungan konsumen yang mengatasi kendala. Namun sebaliknya, legislator juga dapat memasukan substansi yang tidak menguntungkan bagi perlindungan konsumen. Kemungkinan tersebut dapat dihindari, jika proses dengar pendapat dan pengkajiannya berjalan dengan baik. Suatu negara demi untuk kepentingan publik dapat menolak pemasaran produk-produk yang cacat dan mengancam keselamatan masyarakat.

Di Amerika Serikat, terdapat kewajiban bagi produsen, importir, distributor, dan perusahaan pengecer yang harus segera melaporkan informasi mengenai potensi produk-produk berbahaya kepada komisi perlindungan konsumen. Selain itu, Undang-undang di Uni Eropa telah menetapkan ketentuan mengenai prinsip tanggung jawab mutlak atau tanggung jawab tanpa kesalahan dari produsen dalam kasus-kasus kerugian yang ditimbulkan oleh suatu produk yang cacat. Apabila lebih dari satu pihak yang bertanggung jawab untuk kerugian yang sama, maka diterapkan tanggung jawab bersama.

${ }^{29}$ Duane J. Gingerich, "Product Liability in the Asia Pacific", Legal Books, 1995, hlm. 10.

${ }^{30}$ Luke M. Froeb and Paul A. Pautler, "Consumer Protection", Law and Economics Working Vanderbilt University Law School, 2007, hlm. 5, http://ssrn.com/abstractjd=980781.

31 Donna S. Harkness, Lo. Cit., hlm. 553. 
Konsep tanggung jawab produk (product liability) ini pada dasarnya melekat pada produk, karena telah menjadi tuntutan konsumen yang semakin cerdas dan berpengaruh dewasa ini. Ada dua konsep tanggung jawab produk (product liability). Pertama, konsep yang membolehkan siapa saja untuk menuntut perusahaan yang membuat produk berbahaya dan distributomya. Kedua, konsep yang mensyaratkan hanya korban atau ahli warisnya yang dapat menuntut kepada produsen. Dengan demikian konsumen yang menderita kerugian akibat menggunakan produk berbahaya dapat menuntut kepada produsennya. ${ }^{32}$

Persoalan yang muncul adalah bagaimana menentukan pihak yang berhak mengajukan tuntutan, dan pihak yang dapat dituntut dalam konteks globalisasi sekarang? Ada 2 pendapat mengenai hal ini. Pertama, siapapun dapat menuntut produsen dari produk berbahaya tanpa mempertimbangkan hubungan dengan perusahaan pembuatnya. Dengan demikian siapa saja yang berkepentingan dengan produk berbahaya sekalipun bukan konsumen dapat mengajukan tuntutan kepada perusahaan yang membuat produk berbahaya. Lembaga atau pribadi dianggap mewakili pihak konsumen yang menderita kerugian akibat menggunakan produk berbahaya tersebut. Pada umumnya sistem ini berlaku di negara-negara maju seperti Amerika Serikat dan Uni Eropa. Kedua, pihak konsumen atau ahli warisnya yang menderita kerugian akibat menggunakan produk berbahaya yang dapat mengajukan tuntutan. Sistem ini berlaku di negara-negara di Amerika Latin, Pasifik, Rusia dan India.

Sedangkan mengenai tergugat, semua sepakat bahwa konsumen yang menderita kerugian akibat menggunakan produk cacat dapat menuntut produsen, tetapi tidak diperoleh kesepakatan bahwa korban juga dapat menuntut distributor. Masuknya distributor dalam jangkauan kemungkinan untuk dituntut didasarkan pada beberapa alasan. Pertama, distributor merupakan pihak yang berkontribusi atas penempatan produk di pasar. Kedua, apabila korban akibat produk cacat tidak berhasil menemukan produsennya, maka pihak lain yang harus bertanggung jawab atas produk cacat tersebut adalah distributor. Ketiga,

${ }^{32}$ Malia S. Lee, "The Strict Products Liability Sleeper in Hawaii: Toward Exclusion of the Unreasonably Dangerous Standard", University of Hawaii Law Review, Vol. 26, No. 52, Winter, 2003, hlm. 150. 
mendorong pihak produsen agar membuat produk yang lebih aman. ${ }^{33}$ Sir Henry Maine, menyatakan bahwa pertanggungjawaban pihak penyedia produk dan/atau penjual karena adanya ketidaksamaan hak dalam hubungan antara produsen dan konsumen. 34

Dalam konteks perlindungan konsumen, Undang-Undang No. 8 Tahun 1999 membagi produk menjadi 2 (dua), yaitu barang dan jasa. Namun persoalan mendasar atas suatu produk di pasaran adalah siapa yang berhak menentukan kelayakan suatu produk dan otoritas terkait di bidang standarisasi produk. Pandangan lebih progresif menyatakan bahwa suatu produk harus ditentukan melalui putusan pengadilan. Penentuan mengenai apakah suatu produk telah dinyatakan layak atau pantas sesuai dengan tujuan dan manfaatnya, maka pengadilan yang akan menentukan sebagai lembaga yang memiliki wewenang untuk memberikan gambaran terkait hal tersebut. Perlindungan konsumen harus berada pada titik ekuilibrium antara kepentingan konsumen dan bisnis, sehingga tidak hanya di tingkat domestik, tetapi internasional. Dua kepentingan ini menjadi ranah kekuasaan eksekutif, legislatif dan yudikatif. ${ }^{35}$

Dalam penyelesaian ganti kerugian, maka konsep asuransi tanggung jawab produk (product liability insurance) merupakan dasarnya, karena dapat menjamin hak konsumen dan mengurangi beban produsen. Dengan adanya asuransi tanggung jawab produk, maka produsen tidak lagi menanggung secara pribadi tuntutan kerugian dari konsumen yang menderita kerugian akibat cacat produk, melainkan sudah digantikan oleh perusahaan asuransi tersebut. Di samping itu, asuransi tanggung jawab produk dapat mengurangi beban konsumen dan produsen. ${ }^{36}$

Perjanjian asuransi tanggung jawab produk ini berlaku untuk jangka waktu tertentu. Oleh karena itu, dalam prakteknya produsen dapat mengasuransikan satu produk pada beberapa perusahaan asuransi. Asuransi tanggung jawab produk merupakan salah satu jenis asuransi tanggung jawab atas

33 Wendy K. Mariner, "The New Economic and the Unraveling Social Safety; Can Consumer Choice Plans Satisfy Patients? Problems with Theory and Practice in Health Insurance Contract", Brooklyn Law Review, Vol.49, No.98, Winter, 2004, hlm. 493.

${ }^{34}$ Ibid., hlm. 495.

${ }^{35}$ Clifford Fisher, "The Role of Causation in Science as Law and Proposed Changes in Common Law Toxic Tort System", Buffallo Environmental Law Journal, Vol. 9, No. 27, Fall, 2001, hlm. 46.

${ }^{36}$ Sri Redjeki Hartono, Hukum Asuransi dan Perusabaan Asuransi, Sinar Grafika, Jakarta, 2001, hlm. 11. 
risiko gugatan pihak ketiga. Dengan demikian, prinsip dasarnya adalah pertanggungan atas kewajiban hukum yang dibebankan kepada produsen akibat mengkonsumsi atau menggunakan produk yang dihasilkan atau diperdagangkannya.

Di Indonesia, pelaksanaan kegiatan asuransi didasarkan pada beberapa ketentuan dalam Kitab Undang-undang Hukum Dagang (KUHD) dan UndangUndang No. 2 Tahun 1992 tentang Usaha Perasuransian. Sedangkan jenis-jenis pertanggungan yang ditentukan dalam Pasal 247 KUHD didasarkan pada sifat dari suatu peristiwa yang tidak tertentu.

Selain itu asuransi tanggung jawab produk pada dasarnya merupakan bagian dari asuransi pertanggungjawaban, yaitu perjanjian asuransi yang ditutup oleh seseorang untuk mengalihkan atau membagi kewajibannya membayar sejumlah uang terhadap pihak lain karena tanggung jawabnya terhadap perusahaan asuransi dengan membayar premi. Apabila dilihat dari sumbernya, maka asuransi pertanggungjawaban (liability insurance) dapat dibagi dua yaitu asuransi pertanggungjawaban berdasarkan undang-undang dan asuransi pertanggungjawaban berdasarkan perjanjian. ${ }^{37}$

Asuransi tanggung jawab produk ini merupakan bentuk asuransi gabungan dalam arti asuransi yang lahir dari undang-undang dan dapat juga dikategorikan sebagai asuransi yang lahir dari perjanjian, karena gugatan/ tuntutan ganti kerugian konsumen terhadap produsen dapat didasarkan pada tiga hal, yaitu berdasarkan perbuatan melawan hukum (Pasal 1365 KUHPerdata jo. Pasal 19 Undang-Undang No. 8 Tahun 1999), berdasarkan ingkar janji (breach of warranty), dan berdasarkan tanggung jawab mutlak/ strict liability. ${ }^{38}$ Praktek di Indonesia, asuransi pertanggungjawaban diselenggarakan oleh perusahaan asuransi nasional dan perusahaan asuransi joint venture.

Dalam hukum tanggung jawab produk dikenal beberapa jenis kerugian konsumen yang dapat diklaim kepada produsen. Kerugian tersebut dikelompokan sebagai berikut: cidera atau luka pada konsumen/personal injury, kerusakan pada produk atau harta benda lainnya/injury to the product itself or

${ }^{37}$ Ibid., hlm. 15.

38 Inosentius Samsul, Op. Cit., hlm. 253. 
some other property, dan risiko ekonomi murni/pure economic loss. ${ }^{39}$ Selain itu terdapat tiga jenis biaya yang dihasilkan dari suatu kecelakaan, yaitu Pertama, biaya yang berkaitan dengan kerusakan pada pihak yang menderita cidera atau kecelakaan, termasuk biaya untuk rumah sakit dan kehilangan kemampuan untuk memperoleh pendapatan. Kedua, biaya yang disebut dengan the societal cost resulting from accident. Biaya ini relatif karena tidak sama bagi setiap konsumen sebab tergantung dari latar belakang dan sosial ekonominya. Ketiga, biaya perkara di pengadilan. ${ }^{40}$ Berkaitan dengan ganti kerugian secara perdata, maka hukum tanggung jawab produk dapat menerapkan denda kepada pihak produsen sebagai bagian dari penerapan hukum pidana.

Dalam ruang lingkup risiko tanggung jawab produk ini ditentukan juga oleh karakteristik dasar dari model asuransi tanggung jawab produk. Secara konseptual, terdapat tiga perbedaan pokok antara asuransi tanggung jawab produk dengan asuransi jenis lainnya. Perbedaan tersebut adalah objek yang dipertanggungkan, dan ruang lingkup tanggung jawab yang diasuransikan, serta pihak yang terlibat dalam perjanjian asuransi.

Ruang lingkup dan pengecualian tanggung jawab yang terdapat dalam beberapa polis asuransi menunjukan bahwa tidak semua risiko yang menurut hukum dibebankan kepada produsen dapat dialihkan kepada perusahaan asuransi. Selain itu dalam prakteknya terjadi tarik menarik kepentingan antara pihak penanggung dan tertanggung dalam menentukan peristiwa yang menjadi faktor utama atau langsung (proximate cause) timbulnya kerugian konsumen. ${ }^{41}$

Dari perspektif kepentingan konsumen dan pihak yang diasuransikan, semakin luas risiko yang ditanggung maka semakin responsif terhadap kepentingan pihak tertanggung dan kepentingan konsumen. Namun sebaliknya, semakin sempit atau semakin banyak pengecualian maka semakin tidak responsif dan semakin jauh dari harapan produsen dan konsumen untuk memperoleh manfaat dari mekanisme asuransi tersebut.

\footnotetext{
${ }^{39}$ Kimberly Jade Tillman, "Product Defects Resulting in Pure Economic Loss: Under What Theory Can a Consumer Recovery?”, Journal of Product Liability, Vol.9, No.18, USA: Pergamon Press, 1986, hlm. 276. 143.

${ }^{40}$ Jeffrey L. Harrison, Law and Economic in a Nutshel, St. Paul Minnesota, West Publishing Co., 1995, hlm.

${ }^{41}$ Inosentius Samsul, Op. Cit., hlm. 258.
} 
Dalam praktek, asuransi tanggung jawab produk yang ditawarkan di Indonesia merumuskan ruang lingkup risiko yang ditanggung oleh perusahaan asuransi, sebagai berikut:

"The company will indemnify the insured against liability at law for damages and claimant's expenses in respects of (a) accidental injury to persons, (b) accidental damages to property happening during any period of insurance caused by products supplied by the insured from the premises stated in the scheduled to territories within the states limits and in connection with the business". ${ }^{42}$

Rumusan tersebut ternyata tidak berbada dengan rumusan dalam polis standar tanggung jawab produk yang ditawarkan di Amerika Serikat tahun 1985, yang merumuskan sebagai berikut:

"To pay those sums that the insured becomes legally obligated to pay as damages because of 'bodily injury' or property damage' included within the 'product completed operations hazard' to which this insurance applies .... The 'bodily injury' or 'property damage must be caused by an occurance". ${ }^{43}$

Kedua rumusan di atas pada dasarnya menanggung risiko produk yang terdiri dari luka badan dan kerusakan harta benda yang diakibatkan oleh cacatnya produk yang dihasilkan atau diperdagangkan oleh pembuat produk/produsen atau pihak lain (vendor).

Dalam asuransi tanggung jawab produk, cidera fisik (bodily injury) diartikan dengan sakit atau penyakit (sickness or desease) yang diderita konsumen, termasuk kematian yang diakibatkan oleh sakit dan penyakit tersebut. Sedangkan kerusakan harta benda (property damages) diartikan sebagai kerusakan fisik pada harta benda, termasuk hilangnya fungsi harta benda itu atau kehilangan fungsi dari suatu harta benda walaupun secara fisik tidak mengalami kerusakan.

Pada dasarnya perusahaan asuransi tanggung jawab produk menanggung risiko, baik cidera fisik maupun kerusakan pada harta benda yang diakibatkan oleh produk yang telah dialihkan status penguasaannya dari pihak produsen kepada konsumen. Dengan demikian apabila konsumen dirugikan oleh suatu produk ketika produk tersebut masih berada di bawah penguasaan dan pengawasan produsen, maka risiko itu tidak dapat diasuransikan melalui mekanisme asuransi tanggung jawab produk.

\footnotetext{
42 Wirjono Prodjodikoro, Op. Cit., hlm. 9.

${ }^{43}$ Rowland H. Long, Op. Cit., hlm. 114.
} 
Oleh karena salah satu fungsi dari asuransi tanggung jawab produk adalah untuk menanggung risiko kerugian yang akan terjadi terhadap konsumen, sehingga perusahaan asuransi harus mengelola risiko (risk management) sedemikian rupa agar tidak terjadi kerugian terhadap konsumen dan/atau produsen, dengan cara menekan biaya atau jumlah kerugian sekecil mungkin bagi masing-masing perusahaan dan menyerap dana dari produsen yang bersumber dari penerimaan premi. Dengan demikian setiap konsumen yang menderita kerugian akibat menggunakan produk yang cacat dapat melakukan upaya hukum dengan meminta ganti kerugian kepada produsennya, berdasarkan peraturan yang berlaku karena asuransi memegang peran yang sangat penting dalam kegiatan ekonomi. ${ }^{44}$

Di Indonesia, asuransi tangung jawab produk termasuk dalam kategori asuransi kerugian, yaitu suatu perjanjian asuransi yang berisikan ketentuan bahwa penanggung mengikatkan dirinya untuk melakukan prestasi berupa memberikan ganti kerugian kepada tertanggung sesuai dengan nilai jaminan yang dipertanggungkan. ${ }^{45}$ Antara risiko yang dialihkan kepada penanggung dengan kerugian yang diderita oleh tertanggung sebagai akibat terjadinya suatu peristiwa yang tidak diharapkan harus seimbang. Oleh karena itu, asuransi kerugian melarang pembayaran ganti kerugian yang nilainya lebih tinggi dibandingkan dengan nilai kerugian yang dipertanggungkan.

Dengan demikian, asuransi merupakan sarana yang tepat untuk meningkatkan kesejahteraan pelaku usaha dengan mengalihkan risiko kerugian kepada perusahaan asuransi. Fungsi asuransi sendiri pada dasarnya untuk menyebar konsekuensi ekonomi dari peristiwa tertentu yang melampaui banyak pihak, dan mereduksi dampak katastropik dari peristiwa tidak terduga terhadap individu yang ditanggung oleh pihak ketiga. ${ }^{46}$

${ }^{44}$ Sri Redjeki Hartono, Op. Cit., hlm. 12.

${ }^{45} \mathrm{Ibid}$., hlm. 6.

${ }^{46}$ Lewis Bass, "Product Liability Insurance and Small Wind Energy Confersion System", Journal of Product Liability, Vol. 4, No. 12, 1999, hlm. 18. 


\section{Penutup}

Asuransi tanggung jawab produk merupakan bagian dari sistem asuransi umum dalam pembiayaan risiko untuk melindungi produsen sebagai pembeli asuransi atau tertanggung terhadap segala risiko tanggung jawab produsen karena adanya gugatan hukum atau tuntutan dari konsumen yang menderita kerugian akibat menggunakan produk yang cacat. Dalam hal ini peran perusahaan asuransi sebagai penanggung adalah mengambil alih tanggung jawab produsen terhadap risiko terjadinya kerugian akibat cacat produk yang di klaim oleh konsumen sebagai pihak ketiga yang mengalami kerugian akibat adanya produk cacat tersebut.

Dengan demikian pertanggungan asuransi tanggung jawab produk, pada dasarnya untuk melindungi dan menjamin hak konsumen atas tuntutan ganti kerugian kepada produsen. Salah satu faktor penghambat hak konsumen di Indonesia untuk mendapatkan ganti kerugian dari produsen adalah belum adanya suatu lembaga yang dikelola dengan baik sebagai pihak yang bertanggung jawab terhadap konsumen yang menderita kerugian akibat menggunakan produk yang cacat. Oleh karena itu lembaga semacam itu sebaiknya dikelola secara profesional, agar hak-hak konsumen dapat terjamin dan terlindungi dengan baik.

\section{Daftar Pustaka}

Abraham, Kenneth S., "Liability Insurance and Accident Prevention: The Evolution of an Idea", Maryland Law Review, Vol. 64, No. 128, 2005.

Andersen, Ray H., "Current Problem in Product Liability Law and Product Liability Insurance", Insurance Counsel Journal, Vol. 31, No. 62, July 1964.

Bass, Lewis, "Product Liability Insurance and Small Wind Energy Confersion System", Journal of Product Liability, Vol. 4, No. 12, 1999.

Brady, Jillian G., "Consumer Protection in the United States: An Overview", Working Paper Loyola University Chicago School of Law, 2008, http://ssrn.com/abstract=1000226.

Cooper, R. Brent, and Faust, Diana L., "Products Liability", House Bill 4 Symposium Issue, South Texas Law Review Inc., 2005. 
Fisher, Clifford, "The Role of Causation in Science as Law and Proposed Changes in Common Law Toxic Tort System", Buffallo Environmental Law Journal, Vol.9, No.27, Fall, 2001, http:/ /www.westlaw.com.

Friedman, David Adam, "Reinventing Consumer Protection", De Paul Law Review, Vol.57, No.114, Willamette University, 2007, http://ssm.comlabstract $=984082$.

Froeb, Luke M. and Pautler, Paul A., "Consumer Protection", Law and Economics Working Vanderbilt University Law School, 2007, http:/ / ssrn.com/abstractjd $=980781$.

Gaharpung, Marianus, "Upaya Perlindungan Hukum Bagi Konsumen”, Jakarta, 14 Januari 2009, http://Marianusgaharpung.wordpress.comlmakalahhukum/ hukum-perlindungan-konsumen/.

Garner, Bryan A., Black's Law Dictionary, 7th Edition, St. Paul Minnesota: West Publishing Co., 1999.

Gingerich, Duane J., "Product Liability in the Asia Pacific", Legal Books, 1995.

Harkness, Donna S., "Packaged and Sold: Subjecting Elder Law Practice to Consumer Protection Laws", Journal of Law and Policy, Vol. 80, No. 160, 2003, http:/ / www.westlaw.com.

Harrison, Jeffrey L., Law and Economic in a Nutshel, West Publishing Co., St. Paul Minnesota, 1995.

Hartono, Sri Redjeki, Hukum Asuransi dan Perusahaan Asuransi, Sinar Grafika, Jakarta, 2001.

Lee, Malia S., "The Strict Products Liability Sleeper in Hawaii: Toward Exclusion of the Unreasonably Dangerous Standard", University of Hawaii Law Review, Vol. 26, No. 52, Winter, 2003.

Long, Rowland H., The Law of Liability Insurance, Matthew Bender \& Company Incorporated, New York, 1999.

Mariner, Wendy K., "The New Economic and the Unraveling Social Safety; Can Consumer Choice Plans Satisfy Patients? Problems with Theory and Practice in Health Insurance Contract", Brooklyn Law Review, Vol. 49, No. 98, Winter, 2004.

Mayerson, Marc S., "Perfecting and Pursuing Liability Insurance Coverage a Primer for Policyholders on Complying with Notice Obligations", Torts $\mathcal{E}$ Insurance Law Journal, Vol.12, No.24, Summer, 1997.

Mildred, Mark, Product Liability Law and Insurance, Maxwell Publishing, London, 2000.

Nasution, A. Z., Hukum Perlindungan Konsumen, Yogyakarta: Diadit Media, 2001.

Prodjodikoro, Wirjono, Hukum Asuransi di Indonesia, Intermasa, Jakarta, 1987. 
Quinley, Kevin M., "Product Liability Cushions the Blow of Risk Management, How to Bulletproof Your Company from the Minefield in Today's Litigious Society", USA: 2006, http://www.mpomag.comlarticles/ 2006/05/product-liability-cushions-the-blow-of-risk-manage.

Sahoo, Sheeta and Aman Chatterjee, "Consumer Protection", 2009, http:/ / ssrn.com/abstract=1452526.

Samsul, Inosentius, Perlindungan Konsumen, Kemungkinan Penerapan Tanggung Jawab Mutlak, Jakarta: Fakultas Hukum Universitas Indonesia, 2004.

Satrio, J., "Mencemaskan Masuknya Investasi Asing", Kompas, 4 Peb 2006, http:/ / www.fiberindonesia.comlindex.php?option=com content\&task $=$ view\&id $=42 \&$ Itemi $=2$

Schooner, Heidi Mandanis, “Consuming Debt: Structuring the Federal Response to Abuses in Consumer Credit", Loyola Consumer Law Review, Vol. 18, No.36, Loyola University of Chicago School of Law, 2005.

Shuck, Peter H., "Tort Liability to Those Injured by Negligence Accreditation Decisions, Law and Contemporary Problems Autumn”, Private Accreditation in the Regulatory States, Vol. 57, No. 114, 1994.

Soekanto, Soerjono, Pengantar Penelitian Hukum, Universitas Indonesia Press, Jakarta, 1996.

Soekanto, Soerjono dan Sri Mamuji, Penelitian Hukum Normatif: Suatu Tinjauan Singkat, Raja Grafindo Persada, Jakarta, 2005.

Stanovich, Craig F., "Duty to Defend in the CGL Policy", 2002, IRMI Online.

Tillman, Kimberly Jade, "Product Defects Resulting in Pure Economic Loss: Under What Theory Can a Consumer Recovery?", Journal of Product Liability, Vol.9, No.18, USA: Pergamon Press, 1986.

Zulack, John F., \& Jennifer King, "Products Liability Prevention: What Every International Business Should Know About Selling Products in the United States", International Law Practicum Spring, New York State Bar Association, 2003. 